giving numerical expression to the amount of boredom expressed by the audience generally during the reading 0 any particular memoir.

F. G.

\section{RECENT EARTHQUAKES}

$\mathrm{T}$ $\mathrm{E}$ shocks of earthquake in Cashmere continue with unabated violence and even appear to increase in frequency and force. Three severe shocks occurred during the night of the $13^{\text {th }}$ and a smart convulsion on the morning of the I4th. It is now ascertained that 228I lives were lost in the Muzzafferabad district, where at first it was thought there had been no casualties. The earthquake was also felt in Gilghit. Another very severe shock at Baramulla on the 17 th demolished all the buildings which escaped former shocks. At Skardo on the I 4 th and at Srinugur on the 17 th, $I 8$ th, and 19 th, shocks were felt. In the Kamraj district the loss of life exceeds 2700 . The Jheelum Valley, from Srinugur to Dopatta, appears to have suffered most. It is stated that both sides of the river from Sopur to Baramula have been seared with cracks, as also the low alluvial hills in the vicinity. The available data fix the centre of the disturbance in the vicinity of Gurais. It thus appears that in extent and amount of destruction the Cashmere earthquake must rank amongst the great seismic catastrophes of the century.

On Thursday morning last (June I8) a portion of Yorkshire was visited by an earthquake shock. The reports from outlying districts show that the shock extended from the east coast through the Wolds and westwards as far as Headingley, near Leeds. Signalmen on the North-Eastern Railway speak positively as to the vibration and noise. Crockery and glass rattled on the shelves of houses, and at Knottingley and Ferrybridge persons ran from their houses from fear. At Easingwold desks and tables were seen to move, and there was a rumbling noise as of thunder. In some cases there was a severe shaking of houses, and doors were moved. The various reports concur as to the time being 10.50, and it is said there were two shocks. It is a curious coincidence that about an hour previous to this on the same day and in the same region the frightful explosion at the Clifton Hall Colliery took place. Unhappily our knowledge will not permit us to connect seismic disturbances with disasters or mishaps in mines, but we have here a violent and unusual disturbance in the crust of the earth in Yorkshire and an almost simultaneous mining catastrophe in Lancashire.

We have received the following communications with reference to the Yorkshire earthquakes :-

A SLIGHT shock of earthquake was felt here yesterday morning in the favourable stillness of the "Friends" meeting for worship. The time was observed to be about I0.47 a.m. I was seated with my back to the north, when a rumbling sound appeared to be swelling onwards for about two seconds from the south or south-west. I then noticed that the hanging leaf of a small table in front of me (its plane lying east and west) was rattling very distinctly, and immediately I became aware that the back of my seat was shaking me perceptibly. Others heard some of the windows rattling on both the east and west sides of the house, and were shaken by their seats moving slightly; these seats were some of them at right angles to mine. Some of these persons thought the rumbling came from the east; others from the west. One gentleman, sitting in a corner, thought that his right shoulder, against a north partition, was shaken more than his left, tgainst the east wall. Ife also thought that the rumbling came from the south end of the house. The place of worship is about two-thirds of a mile to the north-east of our observatory, which is in lat. $53^{\circ} 38^{\prime} 40^{\prime \prime} \cdot 8$, and long. $\mathrm{I}^{\circ} 20^{\prime} 32^{\prime \prime} .75 \mathrm{~W}$. Nothing was noticed at the time by a man and a boy working in our garden. It is reported in to-day's Leeds Mercury to have been felt at York, Leeds, and Driffield.

WILLIAM SCARNELL LEAN

Flounders College, Ackworth, near Pontefract, June I9

CAPT. STAVELEY, at whose house the recent earthquake of June 18 was felt in a marked degree, gives me the following information respecting it. $\mathrm{H}$ is house at North Dalton (seven miles south-west of Driffield) stands on a slight elevation surrounded with undulating hills common to the Cretaceous formation of the Wolds. The shock occurred. between 10.30 and $10.45 \mathrm{a} . \mathrm{m}$. (the exact time was not noted), and lasted about three seconds, travelling from west-south-west to east-north-east. Mrs. Staveley, who was in her bedroom at the time, felt a slight shock, then a rumbling sound as of thunder, and after that another stronger shock. The servants downstairs felt a distinct rocking, and the bricklayer's boy, on a ladder level with the roof, saw the whole roof heave up and down three times. In the dairy some dishes firmly placed on a high shelf were thrown down and broken, and at the inn on the other side of the road the walls trembled perceptibly, and the bottles and glasses were shaken and knocked against each other. The inhabitants of this and neighbouring villages felt the vibrations more or less distinctiy, but the shock seems to have been greatest at, and in the direction of, Capt. Staveley's house. The colliery explosion near Manchester happened about an hour earlier; is it possible for there to be any connection between the two?

Driffield

The following extracts are from the Hull Express of June $20:-$

Information which reached us yesterday shows that the earthquake-shocks experienced on Thursday in York and Market Weighton werc also felt in more or less degree in other parts of the great shire.

Mr. W. Botterill, of Parliament Street, Hull, writes:"On returning home (Newland Park) from business last evening, my wife informed me that during the morning she had for some seconds very sensibly felt a vibratory motion in the house, which she fully believed to be caused by a slight shock of earthquake, and added that she should confidently expect to find in this morning's papers notices in confirmation thereof. It was, therefore, no surprise to learn from your current issue, and other papers of to-day, that similar effects had been experienced at York, Market Weighton, and clsewhere, about the same hour of the day."

A North Cave correspondent says that at about eleven o'clock in the morning nearly every house was subjected to a slight shaking.

A Driffield correspondent says that at the village of Hutton several residents felt a severe shaking of their houses, and at the same time the inner doors were suddenly moved, crockery upset, and other signs of disturbance were observed. People were so terrified that they cannot very accurately describe the shock, but state they felt a "reeling" sensation.

Another correspondent writing from Driffield says:"Yesterday morning a somewhat severe shock of earthquake was felt at North Dalton, a village about eight miles from Driffield. The shock appcars to have been the most distinctly felt at the residence of Capt. Staveley, which stands in an isolated and elevated position, and the house vibrated from basement to roof for several seconds. A bricklaycr's apprentice who was repairing the roof had a narrow escape of being thrown down, and the greatest alarm was felt by the villagers, who 'ran out of their houses in fear for their lives."

The shock was also distinctly felt in Leeds. In Delph Lane, Wood-house Ridge, the occupants of three houses which adjoin each other noticed it. It resembled the effect which would be produced by the violent shutting of doors, the windows rattling, and there being a perceptible 
vibration of the buildings. The same tremulous motion was also felt in Victoria Road, Headingley, and no doubt in other parts of the town.

At Snaith and neighbourhood similar effects were produced. Mr. Barrett, the postmaster of that town, says the shock was so severe as to cause quite a noise with the goods on the shelves in his shop window vibrating, and he felt the floor under him shake distinctly. At 10.48 a.m. on Thursday morning an earthquake was distinctly felt at Thorne, Hatfield, Epworth, and Eastoft. At various parts of Thorne crockery and glass rattled upon the shelves in the houses, furniture was shifted, and many of the inhabitants were greatly alarmed by the floors slightly descending. At Hatfield Levels also some consternation was caused by the earthquake, which was felt very perceptibly. We have not heard of any damage being done by the shock.

About one o'clock on the morning of the I8th, northwestern Argyleshire was visited by an earthquake. The shock was distinctly felt at Ballachulish, and in many of the houses in the slate quarry district of Glencoe. The shock was felt with distinctness in Clachaig Inn, at the top of Glencoe. It travelled in a south-eastern direction.

Dr. Forel, of Morges, writes that a pretty strong shock was felt on the morning of June 20 , at 5.16 , in the cantons of Neuchâtel, Vaud, Berne, Fribourg, and Geneva, the seismic centre being probably the neighbourhood of the Lake of Neuchâtel. The intensity was No. IV. of the scale of seismic intensity.

\section{THE SCOTTISH MARINE STATION}

$\mathrm{T}$ $\mathrm{E}$ equipment of the Research Station at Granton, Edinburgh, has now been increased by the construction of a system of large tanks provided with a constant circulation of sea-water. These tanks are arranged very nearly according to the plan described in the account of the station and its work which was published in April last. The aquarium itself occupies the ground-floor of the building, whose upper story forms the biological laboratory, and it consists of seven large tanks, five of which are shallow, and two deep, the latter being provided with glass fronts. The pump, which is driven by a steamengine, the high-level reservoir, and the low-level reservoirs are situated at other parts of the premises. One of the deep tanks is being used for the study of the still mysterious life-history of Myxine glutinosa. Last week nearly I 50 specimens of that animal were brought alive to the station from the neighbourhood of St. Abb's Head, where it is very abundant. These were successfully domiciled in the aquarium. As out of three specimens brought alive to the "Ark" (the floating laboratory belonging to the station) on May I, and kept in a small glass aquarium about 15 inches long and 9 inches broad, two are still alive and healthy, there is good reason to hope that there will be no difficulty in keeping a large number alive for any length of time in a tank about 7 feet by 5 feet by 4 feet, which are the dimensions of the one now used for the purpose. It was found in the former experiment that the Myxine when left to themselves, burrowed into the layer of mud which had been placed at the bottom of the small aquarium, and lay for hours motionless, their bedies, with the exception of the extreme tip of the snout, being entirely buried. The snout is protruded for the purpose of respiration, a current of water passing constantly through the nostril into the œesophagus, and escaping at the two respiratory apertures. The normal condition of the animal when not actively engaged in the search for food is evidently to lie thus buried in mud. It is well known to fishermen, at least to those who are employed in line-fishing, that eellets, as Myxine are called by them, are met with almost exclusively on muddy ground. At the place where the creatures are more abundant than anywhere else in the neighbourhood of the Firth of Forth, namely, off St. Abb's Head, the sea-bottom throughout an extensive area consists of soft black mud. A quantity of this mud was brought to the station with the living specimens, and a layer of it 6 or 8 inches in depth placed at the bottom of the tank in which the Myxine were to be kept. The animals are now thickly scattered through the layer of mud, like earthworms in garden soil.

Some of the shallow tanks are being used for the studv of the reproduction of the oyster. Supplies of oysters are being obtained from various sources, and before long a series of experiments as to the conditions necessary to the life of the oyster larvæ will be carried out. It is hoped, as the least result from this work, that new interest will be aroused in this country in the question of the scientific artificial cultivation of oysters.

The opportunities afforded for research by the laboratory and new aquarium cannot be fully utilised by those now working at the Station, and biologists who would come and carry out original work at the Station would be gladly welcomed.

A temporary branch of the station is now being organised at Millport, on the Firth of Clyde. It will be open during the months of July and August. The floating laboratory known as the "Ark" will be moored next week in still water off one of the small islands in the Bay of Millport, and the yacht Medusa will be stationed there for the purpose of dredging and providing material for study. Several naturalists have mad e arrangements to carry on work at Millport during part or whole of the time that the "Ark" will be there : amongst others the Rev. A. M. Norman, Prof. W. A. Herdman, of University College, Liverpool, Mr. David Robertson, of Glasgow; Mr. J. Harvey Gibson, Mr. J. R. Henderson. Mr. John Murray, convener of the Committee, entrusted with the management of the Scottish Marine Station, will be at Millport during the greater part of the time. It is hoped that one result of the work will be the preparation of an account of the fauna of the Firth of Clyde which will include, besides the results of the investigations to be carried on, the results of the previous work in the same field. As several of the experienced naturalists mentioned above are already familiar with the fauna of the Firth, a publication on the subject produced by their cooperation will be complete and authoritative. Any naturalists who may wish to carry on research at the Millport temporary station are invited to communicate with Mr. John Murray.

\section{J. T. CUNNINGHAM}

COMPOSITE PORTRAITS OF MEMBERS OF THE NATIONAL ACADEMY OF SCIENCES

THOSE of the members who were present at the Washington meeting of the Academy last spring will remember that, at the request of Prof. Brewer and myself, they sat for their separate photographed portraits for the purpose of obtaining an experimental composite picture. Prof. Baird kindly offered the facilities of the photographic department; and the pictures taken by Mr. Smilie, the photographer in charge, bear the same stamp of excellence that characterises so generally the work of that department of the National Museum.

As only one or two previous attempts, I believe, have been made to produce composites in this country, I will state briefly what they are, and how they are made.

The idea in its broadest sense was conceived and applied by Francis Galton for the purpose of obtaining an average or type portrait-i.e. a picture that should show the features that are common to a group of individuals, and exclude those that are purely individual. It is clear that, in proportion as this result is attainable, the method will be of value in obtaining a clear conception of the external characteristics of any given type or class.

1 From Science, to the editor of which we are also indebted for the use of the photographic plate accompanying the article. 